\title{
Chapter 1 \\ Agrarian Metabolism: The Metabolic Approach Applied to Agriculture
}

In this chapter, we describe the theoretical and methodological background of this work. Our aim was to offer a new perspective on the evolution of Spain's agricultural sector over the last century, moving the focus away from growth capacity towards sustainability. We wished to discover whether the sector had been able to grow over time without deteriorating its social and ecological resources. To tackle this question, we chose the framework of Social Metabolism. Within so-called Sustainability Science, this framework currently provides the broadest capacity of analysis. The present research was thus conducted using the methodological tools included within Material and Energy Flow Accounting (MEFA). MEFA tools have been largely developed by the Sustainable Europe Research Institute (SERI), the Wuperthal Institute and the IFF-Social Ecology of Vienna (Economy-Wide. Material Flow Accounting, $E W-M E F A)$. The methodologies are designed to obtain data that support the analysis of the biophysical trajectories of economies and societies, both today and throughout history. They also measure the biophysical relationships between territories, describe and characterize resource consumption and the ways in which resources are appropriated. Sufficiently consistent data can be obtained allowing to evaluate the degree of sustainability of the relations between a given society and its environment. MEFA thus constitutes an appropriate instrument to study the material aspects of socioecological transitions.

Few studies, however, have adopted this methodology to analyze biomass production and its role in the economy at large (Schandl and Schultz 2002; Krausmann et al. 2008a, b, 2011; Kovanda and Hak 2011; Gierlinger and Krausmann 2012; Singh et al. 2012; Infante et al. 2015). Most studies focus on the present and their time frame of analysis is fairly limited (Risku Norka 1999; Risku-Norja and Mäenpää 2007; for a review of the state of the art, see Infante et al. 2015). Estimates of food system metabolisms (Wirsenius 2003) or agri-food (Heller and Keoleian 2003; Infante et al. 2014) and analyses of global and continental biomass flows (Krausmann et al. 2008a, b) have also been carried out. Nevertheless, none of these works neither applied the methodology to the agrarian sector nor have they gone into sufficient historical depth to study the transition to the industrial metabolic regime. One work 
analyzes the changes in land uses and the energy transition in agriculture between 1830 and the year 2000 in Czechoslovakia (Kusova et al. 2008). Recently, a complete study entitled Social Metabolism of Czech Agriculture in the period 1830-2010 (Greslova et al. 2015) was published for the same country.

Moreover, the limited number of studies which have addressed the evolution of land biomass flows throughout the 20th century have been conducted mostly on a local scale (Krausmann 2004; González de Molina and Guzmán 2006; Cunfer and Krausmann 2009; Garrabou and González de Molina 2010; Infante 2011; García Ruiz et al. 2012; Tello et al. 2012; Infante et al. 2014c). Virtually no study has addressed the issue in a wider context, i.e., the nation-state. Therefore, very few works have attempted to adapt Social Metabolism methodologies to agriculture. The metabolic approach has, in fact, an enormous heuristic potential. Nonetheless, the methodology is not yet capable of providing biophysical data and indicators that account for the specificity and complexity of agricultural activity. In this book, we present a preliminary calculation method adapted to the distinctive features of agriculture. This method combines different metabolic traditions (EW-MEFA, MuSIASEM, etc.) with the arsenal of knowledge, theories, and concepts proper to Agroecology. We call this completely original adaptation and synthesis approach Agrarian Social Metabolism or Agrarian Metabolism.

\subsection{Agriculture and Social Metabolism: The Metabolism of Agroecosystems}

Social Metabolism (hereon SM) refers to the set of theories and methodological tools that allow analyzing a society's biophysical behavior (Adriaanse et al. 1997; Matthews et al. 2000; Haberl 2001; Weisz et al. 2006). It provides valuable information to assess a society's environmental sustainability and has even turned into a new perspective on human beings' relationships with their physical environment, that is, with flows of energy, materials and information (Fischer-Kowalsky and Haberl 1997, 2007; Sieferle 2011; González de Molina and Toledo 2011, 2014). The term emerged from an analogy with the biological concept of metabolism, given that relationships that humans establish with nature are always twofold: individual or biological and collective or social. On an individual scale, humans extract sufficient amounts of oxygen, water, and biomass from nature per unit of time to survive as organisms, and excrete heat, water, carbon dioxide, mineralized, and organic substances. At the social level, groups of individuals connected in different ways, through relationships or links, are organized in such a way as to guarantee their subsistence and reproduction. They also group together to extract matter and energy from nature through meta-individual structures or artefacts and excrete a whole range of waste or residues. Social Metabolism can be defined, therefore, as the way in which human societies organize their exchanges of energy and materials with their natural environment (Fisher-Kowalski and Haberl 1994; Fisher-Kowalsky 1998, 2002; Giampietro and 
Mayumi 2000; Giampietro et al. 2011) with the purpose of reversing the entropic process they are subject to, like all living beings (González de Molina and Toledo, 2014). In this sense, human societies carry out two basic material tasks: on the one hand, they produce goods and services and distribute them among society's individuals; on the other, they reproduce the conditions that make production possible, thus gaining stability over time. A substantial share of social relations is therefore oriented towards the organization and maintenance of exchanges of energy, materials, and information. Its mission is to configure and feed the "funds" (Georgescu-Roegen 1971) that societies build to generate goods and services, i.e. to counteract the law of entropy and thus generate order. Such funds are fed, that is, they are maintained and reproduced through the exchange of energy and materials with the environment. This enables us to understand the relationship between society and nature as a metabolic relationship. Social Metabolism is, in fact, a metaphor that borrows a concept taken from biology and applies it to the world of relations between society and nature.

$\mathrm{SM}$ is thus an analytical tool applied to socio-ecological relationships, whatever their scale or territorial scope. It can, therefore, be applied to agriculture. Consequently, Agrarian Social Metabolism (ASM) or Agrarian Metabolism (AM) can be described as the exchange of energy, materials, and information that agroecosystems perform with their socio-ecological environment. The purpose of metabolic activity is that of appropriating biomass to satisfy human species' endosomatic consumption directly or indirectly through livestock while providing basic ecosystem services. AM has also tried to satisfy the exosomatic demand (raw materials and energy) of societies with an organic metabolism and continues to do so, to a lesser extent, in industrial societies. To accomplish this, society colonizes or seizes a part of the available land. Within this territory, it establishes varying degrees of intervention or interference in the ecosystems' structure, functioning and dynamics, giving rise to different types of agroecosystems. In other words, AM refers to the appropriation of biomass by members of society by managing the agroecosystems present on the land (Guzmán Casado and González de Molina 2017).

Why should we consider, however, "agroecosystems" to be the subjects of AM? Because they constitute the basic unit of metabolic activity: these ecosystems are manipulated and artificialized by human beings in order to capture and convert solar energy into some particular form of biomass that can be used as food, medicine, fiber or fuel (Altieri 1989). From a thermodynamic point of view, they can also be considered as complex adaptive systems that dissipate energy to counteract the law of entropy (Prigogine 1978; Jørgensen and Fath 2004). To do this, they exchange energy, materials, and information with their environment (Fath et al. 2004; Jørgensen et al. 2007; Swannack and Grant 2008; Ulanowicz 2004). Compared to ecosystems, that still retain their capacity to self-sustain, self-repair and self-reproduce, agroecosystems are unstable, requiring external energy, materials, and information (Toledo 1993; Gliessman 1998).

The flows are exchanged through work or manipulations that aim at ensuring the production of biomass and its reiteration over successive cycles of cultivation or breeding, interfering in the carbon, nutrients and hydrological cycles and in the mechanisms of biotic regulation. In traditionally managed agroecosystems, this input 
of additional energy and materials comes from biological sources: human work and animal labor. Dependence on the land is maintained in a strict sense. In industrially managed agroecosystems, additional energy and materials also come from the direct and indirect use of fossil fuels as well as metallic and non-metallic minerals. In such systems, most of the energy generated as biomass is directed out of the system in the form of food or fiber as well as crop residues. The latter are not allowed to remain within the system and this contributes to important internal processes. Therefore, it is also necessary to import a large amount of biomass from other agroecosystems to ensure reproduction. These agroecosystems are mere "energy transporters" and can hardly be considered sustainable (Gliessman et al. 2007, 17). In short, they are part of society's general metabolism, specifically dedicated to the appropriation of photosynthesis products. From a metabolic point of view, the reproductive dynamic of agroecosystems is peculiar. Their sustainability, as artificialized ecosystems, also depends on their level of biodiversity, the maintenance of fertile soil, etc. This means that part of the generated biomass must be recirculated to meet both productive and basic reproductive functions of the agroecosystem itself: seeds, animal labor, organic matter in the soil, functional biodiversity, etc. The thermodynamic rationale underlying this characteristic was developed by Ho and Ulanowicz (2005) and, later by Ho (2013) when they related sustainability to dissipative low entropy structures. Ecosystems, as dissipative structures that can consume large amounts of energy or the reverse, can be structured in such a way that their entropy is low. This characteristic of ecosystems also works at different scales for agroecosystems and even for AM as a whole. Like ecosystems, agroecosystems constitute an arrangement of biotic and abiotic components in which living systems predominate and respond to what has been called "thermodynamics of organized complexity" (Ho and Ulanowicz 2005, 41, 45). This means that, going beyond the point raised by Prigogine (1962), an agroecosystem can be "far from thermodynamic equilibrium on account of the enormous amount of stored, coherent energy mobilized within the system, but also that this macroscopically non-equilibrium regime is made up of a nested dynamic structure that allows both equilibrium and non-equilibrium approximations to be simultaneously satisfied at different levels". In this sense, the really decisive aspect of ecosystems is not only the flows of energy and materials that keep them away from thermodynamic equilibrium but also their capacity to capture and store the energy that circulates inside them and transfer it to its different components (Ho and Ulanowicz 2005, 41, 45). This depends on the quality and quantity of circuits or internal loops through which the energy flows circulate as well as whether they are able to compensate for the entropy generated somewhere in the ecosystem by the negative entropy generated in another system within a given period of time. As Bulatkin $(2012,332)$ argues, "the agroecosystem as a natural-anthropogenic system has its own biogeocenotic and biogeochemical mechanisms and self-regulation structures, which should be used to reduce anthropogenic energy costs". That is, it contains cycles that, according to Ulanowicz (1983), have a "thermodynamic sense": "Cycles enable the activities to be coupled, or linked together, so that those yielding energy can transfer the energy directly to those requiring energy, and the direction 
can be reversed when the need arises. These symmetrical, reciprocal relationships are most important for sustaining the system" (Ho and Ulanowicz 2005, 43).

For example, in organic or agrarian metabolic regimes (González de Molina and Toledo 2011, 2014), agroecosystems used to function in an integrated manner. Biogeochemical cycles clearly went beyond the cultivated lands and extended over large parts of the territory. The increase in entropy that occurred in the most intensively cultivated areas (irrigation or hedges, in the case of the Mediterranean) was usually compensated by the import of nitrogen through livestock (manure) from other areas of low entropy such as forest areas. The result was a metabolic regime that was also of low entropy. Spatial heterogeneity and agrosilvopastoral integration were key for articulating the different circuits that captured, stored and transferred energy. ${ }^{1}$

This explains why, when different agroecosystem components are adequately articulated, it is possible to substantially reduce incurred land costs whenever biomass is produced, and thus generate the largest amount of biomass at a minimal land cost (Guzmán and González de Molina 2009; Garzón et al. 2011, Guzmán et al. 2011). In this sense, net primary production is found to correlate positively with the functional integration of different land uses in terms of territorial efficiency. The bigger the amount of energy is captured and stored in the internal cycles of agroecosystems, the smaller the amount of energy that will have to be imported from outside (Guzmán Casado and González de Molina 2017). For this reason, it is often commented (Gliessman 1998) that the more an agroecosystem resembles natural ecosystems in its organization and functioning, the greater its sustainability.

Each of the AM's forms of organization leaves their particular mark on the territory, configuring specific landscapes and specific agroecosystem arrangements. The landscape is the visible mark left on the territory, although hidden marks may materialize in a different, sometimes distant, territory from which natural resources (land embodied, virtual land) are imported (Guzmán and González de Molina 2009; Garzón et al. 2011, Guzmán et al. 2011; Infante et al. 2018). In pre-industrial agriculture, agroecosystems needed to appropriate large amounts of land to produce useful biomass and function correctly. Industrialized agriculture does not incur this cost, as it is fed by energy sources and materials that come from the subsoil. In this sense, the extent to which industrialized agriculture landscapes are simplified depends on the extent to which these internal circuits are reduced within the agroecosystems.

In short, agroecosystems can be understood as dissipative structures built and maintained by humans (Prigogine 1947, 1978; Jørgensen and Fath 2004) in order to provide energy and useful materials for society, generating order or negentropy. This way, agroecosystems can be "improved" in order to increase their net primary productivity (NPP): for example, by providing them with productive infrastructures that maximize water (irrigation channels) or available land (terraces) or biodiversity (hedges, landscape mosaics), or recreating outdoor environmental conditions

\footnotetext{
${ }^{1}$ As pointed out by Sieferle $(2001,20)$, different land uses were linked to different types of energy. Cultivated lands were associated with the production of metabolic energy to provide human food; the pasture land that fed farm animals was associated with mechanical energy and forests with the thermal energy that provided the fuel needed for cooking, heating and manufacturing.
} 
(greenhouses). Toledo and Barrera-Bassols (2008) gathered a large number of cases where peasants improved the productive capacity of agroecosystems across the globe for thousands of years. This investment in "built capital" has also been called Landesque Capital (Widgren 2007). The concept should include the infrastructure of roads, houses and warehouses or buildings with productive uses that have been built over time and are essential for agricultural activity itself as well as for current soil productivity levels. However, due to the difficulty in achieving suitable accounting, we chose to leave this section aside, recognizing nonetheless that an increasingly significant share of energy and materials are dedicated to the maintenance and improvement of these infrastructures.

\subsection{Funds and Flows in Agrarian Metabolism}

We have defined AM as the exchange of energy, materials, and information between agroecosystems and their socio-ecological environment. This exchange is composed of flows that go in and out, as described in the EW-MEFA methodology. However, our proposal not only quantifies these flows but also carefully measures whether or not these flows maintain the dissipative structures or fund elements they are endowed with. The distinction between flows and funds was borrowed from GeorgeuscuRoegen (1971) and Giampietro et al. (2014) who incorporated it into the MuSIASEM methodology. According to Georgescu-Roegen, the economy's ultimate goal is not the production and consumption of goods and services, but the reproduction and improvement of the processes necessary for their production and consumption. This different understanding of economic activity's main objective implies that from a biophysical point of view, we need to shift our attention away from energy and material flows and instead focus on fund elements: we must center our analysis on whether fund elements are improved or at least reproduced during each productive cycle. In other words, our focus switches from the production and consumption of goods and services to sustainability, and whether both production and consumption can be maintained indefinitely. Within this framework, it is essential to distinguish between flows and funds. Flows include energy and materials that are consumed or dissipated during the metabolic process, such as raw materials or fossil fuels. The rhythm of these flows is controlled by external factors-relating to the accessibility of the environment's resources in which the metabolic activity unfolds - and by internal factors - related to the processing capacity of energy and materials, relying in turn on the technology used and the knowledge to manage it. Fund elements are dissipative structures that use inputs to transform them into goods, services, and waste, i.e., into outputs, within a given time scale; they remain constant during the dissipative process (Scheidel and Sorman 2012). They process energy, materials and information at a rate determined by their own structure and function. To do so, they need to be periodically renewed or reproduced. This means that part of the inputs must be used in the construction, maintenance and reproduction of the fund elements, limiting, of course, their own processing rhythm (Giampietro et al. 2008). The quantities 
of energy and materials invested in the maintenance and reproduction of the fund elements cannot be employed for end uses. These types of elements can even be improved over time, when energy and materials are allocated for this purpose.

The MEFA methodology, the best known social metabolism methodology, has been criticized (Giampietro et al. 2014, 29) and with good reason: it does not take into account dissipative structures proper to an agroecosystem as in our case, nor the different types of flows that feed them. The MEFA methodology reduces all flows to units of energy (MJ) or weight (t) to be able to add them and does not differentiate between their varying qualities and purpose. What this approach actually does is transfer a prevailing idea from conventional economics, whereby only the existence of inputs and outputs are taken into account in metabolic accounting. This preferential consideration of the transfer of energy and materials has no thermodynamic basis and is therefore not useful when it comes to describing the biophysical functioning of a society's economic activity and its degree of sustainability.

Agroecosystems are, as we have said, dissipative structures that can be decomposed, in turn, into other structures, be they social or ecological, which compose them. To consider each one of them individually would render our proposition so complex, it would lose its heuristic nature. For this reason, only essential dissipative structures or fund elements for the reproduction of agroecosystems themselves and the provision of their services in AM are included. However, such funds may be decomposed into other fund elements in order to refine, if deemed necessary, the analysis. We will come back to this point when examining the environmental impacts of Spanish agriculture's industrialization. For the purposes of this research, four fund elements were taken into account: land, livestock, agrarian population and technical means of production (or technical capital today). However, it is relevant to differentiate between fund elements of a biophysical nature and fund elements of a social nature since they are not reproduced in the same way. The four funds are closely connected and represent the fullest manifestation of the socioecological relationships at the heart of each agroecosystem and at the center of the metabolic exchange. The articulation between the four fund elements is fundamental, as we shall see later, to explain metabolic dynamics.

Each fund element has a different either biophysical or social nature, and, therefore, each fund element works with different quality flows and different metrics. As pointed out by Giampietro et al. $(2014,29)$, the flows' characteristics are closely related to the fund they come from. A territory is colonized or land is appropriated by society to generate useful biomass flows; it is usually measured in hectares and subdivided into different uses that produce vegetal biomass, expressed in tons of vegetal biomass per hectare $\left(\mathrm{t} \mathrm{ha}^{-1}\right)$ —or its equivalent in energy, $\mathrm{MJ} \mathrm{ha}^{-1}$ —or net primary productivity (NPP). The livestock fund element is the source of flows directed to society as well as to the agroecosystem itself, providing animal biomass for raw materials, food and, to a much lesser degree, energy or services such as traction or manure. It is usually measured in standard livestock units of $500 \mathrm{~kg}\left(\mathrm{LU}_{500}\right)$ and the flows it generates are expressed in $\mathrm{kg}$ or $\mathrm{t}$ of animal biomass $\mathrm{ha}^{-1}$ or LU or $\mathrm{MJ} \mathrm{ha}^{-1}$ if the flows are expressed in energy units. The agrarian population is the fund element which represent the human work flows. They are usually measured in 
hours or days of work (hours or days/year ${ }^{-1}$ ). Finally, the "means of production" fund brings together the supply of production tools that generate mechanical work flows or vegetal health services and other services: its size and composition vary significantly according to whether the agrarian system is industrial or pre-industrial. In our case, we will examine a period of transition from traditional organic agriculture to industrial production, during which mechanical instruments stand out from the rest of the work tools. It is usually measured, for example, in terms of installed capacity, expressed in $\mathrm{Kw}$ of power or cv, and its flows in $\mathrm{Kw} / \mathrm{h}^{-1}$ or $\mathrm{MJ} \mathrm{ha}{ }^{-1}$, etc.

Whatever they may be, fund elements require a quantity of energy in terms of biomass and human work that must be taken into account for each production process. The process of industrialization of agriculture has consisted in substituting the agroecosystems' biogeochemical circuits with working capital that depends on resources outside the agrarian sector, usually via markets. This explains a fundamental difference in the metabolic functioning of traditional and industrialized agroecosystems: the reproduction of fund elements was possible through biomass flows in organic metabolic regimes; but under the industrial metabolic regime, external fossil energy flows are widely reproduced by social funds and can cause environmental deterioration when attempting to reproduce biophysical funds, especially agroecosystem services. For example, trophic chains that support both edaphic life and the agroecosystem's biodiversity can generally only be fed with biomass. Deterioration of colonized or appropriated land cannot be compensated using energy and external materials or any other resource than vegetal biomass. In this way, the industrialization of agriculture can be interpreted as the process of replacing dissipative structures of a biophysical nature, that belong to agroecosystems and have been maintained by peasants through integrated management, with man-made dissipative structures or, to put it in economic terms, with means of technical production obtained through markets and, to a lesser degree, from State intervention.

In AM not only are biophysical flows exchanged, but also flows of information. They are usually excluded from metabolic methodologies, perhaps due to their complexity and difficulty in measuring them. However, these flows have the capacity to order and organize components of physical, biological and social systems. They are therefore essential to understand not only the specific configuration of metabolic regimes but also their dynamics. We have thus attempted to integrate them into our proposition. As they cannot all be taken into account given their inherent complexity, we selected the information flows with the biggest explanatory capacity regarding farmers' decisions. Agricultural work is also considered as a workflow containing decisive information that organizes agroecosystem structure and functioning. Consequently, we assumed that these decisions were directly influenced by the monetary remuneration that farmers receive in exchange for the sale of their products. Therefore, they constitute a suitable proxy for synthesized information flows. In other words, for the purposes of this research, information flows are defined as follow: flows originating in the agrarian population fund element, in the form of work and incorporated management decisions; and monetary flows stemming from the agroecosystem's social environment and ending up in this population fund in the form of money obtained in exchange for production. 
Monetary flows represent a specific type of flow which, from a metabolic standpoint, have multiple purposes: they allow to closely articulate the biophysical and social components of social metabolism itself. As suggested by Swanson et al. (1997), money is a commodity but it is also information. Even if it is understood as a measure of the value of entropy, it can be considered according to its capacity to reduce the levels of a social system's future entropy (González de Molina and Toledo 2014). Money, expressed in relative prices, has transmitted information that has enabled to largely explain — especially in societies with monetized exchanges — the behavior of social agents, in our case that of farmers. This does not mean that markets, as they are organized today, have determined farmers' behaviors based on relative prices. Markets were not always the main or only way to exchange goods and services. Therefore, their dynamics only explain productive decisions in contexts of commodified economies. In organic metabolism societies, seigneurial rights, for example, imposed monetary levies on farmers and were based on feudal law, not on markets; but ultimately, they constituted monetary exactions that forced peasants to sell part of the harvest to be able to pay them. The price of agricultural products, even in "imperfect" markets, forced peasants to take production decisions. The situation is less ambiguous in market societies, where relative prices are the most relevant indicator or source of information. Nevertheless, relative prices determine farmers' behaviors, according, for example, to cost-benefit calculations; the decisions they make are usually based on multiple and weighted criteria, as in the case of other economic agents. We are also aware of other non-monetary information flows that also have a bearing on farmers' decisions, such as public policies, the institutional framework, etc., and even the rural worlds' successive cultural values along the twentieth century. Monetary flows also reflect the large array of cultural and institutional factors but the extreme complexity of the subject would make it impossible to consider them all. Consequently, we will use the agrarian sector account, elaborated from national accounts, to quantify and analyze AM monetary flows. The prices received by farmers, the prices paid for inputs and agricultural income will constitute the major macromagnitudes used as information flows in the sector, as we will see in Chap. 4.

To summarize, we have defined four fund elements belonging to agroecosystems. They receive flows of energy, materials and originate, in turn, outflows in the form of biomass that society remunerates through monetary flows. These monetary flows, which are also information flows, stop at farmers, who through their agricultural labor, that is through their tasks, maintain and reproduce the funds. Monetary flows are input information flows and agroecosytems' management decisions are output flows. Consequently, energy and material flows, both inputs and outputs, can be broken down into productive, reproductive or maintenance flows of fund elements; meanwhile, information flows are composed of monetary flows (input) and human work flows (output) and normally have a reproductive role. The main hypothesis in this research is that the reproductive capacity of these latter flows determines the dynamics of agroecosystems and the dynamics of the agrarian sector as a whole. 


\subsection{The Appropriation of Biomass and Colonization of the Territory. Biophysical Funds (Land and Livestock)}

The territory is the main element in any agroecosystem, since biomass production requires land for the photosynthetic process to take place. Therefore, the first task of AM consists of colonizing the ecosystems (Cook 1973) and appropriating a part of their net primary productivity (NPP). Through colonization and appropriation, farmers conduct three basic types of intervention on the territory, thus affecting different ecosystems (González de Molina and Toledo 2011). The first intervention consists in hunting, fishing, gathering, as well as certain forms of extraction and livestock by foraging on the original vegetation: this type of intervention does not cause substantial changes in the structure, architecture or dynamics of ecosystems. The second type of appropriation consists in disarticulating or disorganizing ecosystems to introduce groups of domesticated species or species in the process of being domesticated, as in the case with all forms of agriculture, livestock, forestry, and aquaculture. While in the case of the first type of appropriation, ecosystems' intrinsic or natural capacity to self-maintain, self-repair, and self-reproduce is not affected, in the second case, ecosystems lose these latter abilities and require external energy (whether human, animal or fossil), as well as materials and information to sustain themselves. Over the last decades, a third form of appropriation has emerged responding to conservationist actions by public administrations or non-governmental organizations that seek to preserve natural or regenerating areas. They also aim at providing ecosystem services. ${ }^{2}$ The distinction between the first two types of intervention is of special interest in our work because as we will observe later, they have coexisted and been combined in different ways throughout the study period.

Consequently, an agroecosystem may also contain appropriated areas where the ecosystem is minimally subjected to manipulation or intervention while remaining inseparable from its territorial arrangement. Different units of biomass appropriation can coexist there, some obtained by means of hunting and gathering and others by plant manipulation. This situation is more visible when beyond the scale of plots, we move up to observe the territorial arrangements an agroecosystem must necessarily be made of in terms of different land uses. We need to specify this because agroecosystems are commonly confused with cultivated areas. Agroecosystems, however, make up coherent and articulated units of analysis: biogeochemical flows circulate within them and, therefore, human appropriation gives rise to different degrees of intervention (Guzmán and González de Molina 2000; González de Molina and Toledo 2011, 2014; Guzmán Casado and González de Molina 2017). This also applies to plants that inhabit agroecosystems, since cultivated plants are often the only ones to be taken into consideration. Moreover, only the aerial parts of these plants are taken into account, while the root biomass, often the crop residues or the adventitious flora

\footnotetext{
${ }^{2}$ Although it is possible to find examples in the past of protection of natural spaces through religiouscultural practices such as sacred forests.
} 
are ignored. An agroecological approach to AM must be based on all the biomass produced within its limits, that is, all the net primary productivity. As we shall see, the reason is that when defined as a fund element, territory or land reproduction depends directly or indirectly on the total amount of produced biomass, not only on the harvest. Consequently, the colonized territory a society disposes of to develop its AM tends to be fragmented into different categories or land uses, such as croplands, pasture lands, and forest lands depending on the degree and type of its dedicated management. Each one of them can be subdivided in turn into different categories depending on their specific or multiple uses and labor intensity.

The other biophysical fund element under consideration is livestock, whose basic function is to provide useful animal biomass to society in the form of food (meat, milk, fat, etc.) or raw materials (wool, skins, etc.) and certain services, among which some essential ones such as manure to renew soil fertility. As mentioned earlier, livestock volume is measured in international livestock units (LU of $500 \mathrm{~kg}$ ), as it allows to reduce different livestock species to a common denominator. In societies with organic metabolism, livestock was adapted to the soil and climate conditions of each territory and to the interests of the society on which it depended. Livestock, thanks to its functional biodiversity, mediated the agroecosystem's different ecological processes. As a result, its composition had to be diversified, to take advantage of the different available food resources (herbaceous, arboreal pastures, crop residues, feed, etc.), in very different environments (wetlands, steep slopes, etc.) and generate goods and services of a varying nature (food, work, fiber, etc.). Therefore, the herds had to present a certain degree of diversification and balance based on land availability and society's needs and resources, without being excessively simplified or specialized. This explains the diversity of livestock breeds, species and multiple uses made of animals (traction, reproduction, production of food and raw materials). This was the situation when no biomass flows were imported from third countries. Today, growing transport capacity and differences in production costs have facilitated and generalized the import of large quantities of vegetal biomass to feed livestock that in certain cases can no longer be maintained, due to its volume and nature (monogastric or granivorous), by native agroecosystems. A huge amount of livestock is maintained based on these imported biomass flows. This livestock is highly specialized in meat or milk production, it is contained and composed of a few breeds, designed to meet the growing demands of meat and dairy products. This growing consumption has characterized western diets, including the Spanish diet, over the last decades. Therefore, livestock, in its role of biophysical fund, can only be reproduced, maintained or increased through a constant flow of biomass - whether domestic or imported-that is mostly vegetal, but not only vegetal.

The biophysical fund elements of an agroecosystem require therefore a certain amount of energy and materials in the form of biomass for reproduction and maintenance. In addition, trophic chains that support both edaphic life and biodiversity can generally only be fed with biomass. In this sense, it is worth recalling the idea, expressed by ecological economists, that natural capital cannot be replaced by manufactured capital (Ayres 2007; Häyhäa and Franzese 2014, 125), just as not all types of energy are interchangeable or have the same use (Giampietro et al. 2010). That is, 
the biophysical elements of an agroecosystem cannot be sustained using oil or coal or the fuels that derive from them.

On the other hand, ecosystems, including those appropriated by society (agroecosystems), generate ecosystem service flows, some of which are directed towards its renewal (De Groot et al. 2003; Ekins et al. 2003; Millennium Ecosystem Assessment 2005; Folke et al. 2011). According to Schröter et al. (2014), each agroecosystem has a specific capacity to provide these services, in accordance with their edaphoclimatic conditions. Since agroecosystems are human-being-dependent ecosystems, the quantity and quality of the services that they provide depend on the way they are managed. An adequate provision of services will depend on the agroecosystem's health, that is, on the sustainable state and size of its fund elements (Cornell 2010; Costanza 2012). Conversely, the degradation of an agroecosystem's fund elements can lead to reductions in the amount of ecosystem services it provides (Burkhard et al. 2011). Services are usually grouped into four categories: provisioning, regulating, supporting and cultural services. Provisioning includes the extraction of goods (e.g., wood, firewood, food, and fiber); regulatory services help to modulate ecosystem processes (e.g., carbon sequestration, climate regulation, pest and disease control and recycling of waste or residues); support services sustain the provision of all other categories (e.g., photosynthesis, soil formation, nutrient recycling); while cultural services contribute to spiritual well-being (e.g., recreational, religious, spiritual and aesthetic) (de Groot et al. 2010).

\subsection{Social Fund Elements (Human Work and Technical Means of Production)}

Agroecosystems process energy and materials to produce biomass thanks to human labor. As we have seen, human work has a characteristic that distinguishes it from other funds: it incorporates information flows. The origin of these flows is not farmers alone but also the household they are part of. Consequently, the fund element considered in this work - unlike that established by other metabolic methodologiesis the "agrarian population", composed of domestic groups or households that are dedicated to this activity. There are three reasons for this, based on the distinction between flows and funds. Firstly, because the continuation of the human work flow depends on the time investment in other tasks carried out by the entire household. For example, time devoted to care, which are reproductive tasks from the physiological point of view (overheads), or to social and educational activities, which from a social perspective, would correspond to reproductive activities. Second, because maintaining agroecosystems in good productive conditions requires performing maintenance tasks that are not usually considered to be part of working hours directly related to agricultural production or are effectively paid. And lastly, because agricultural labor has usually been performed by farmers with the help of the family, so agrarian work is essentially family work. As a result, in our research, we not only considered the 
number of individuals engaged in agricultural work but also their families who are responsible for "producing" the agricultural workers and who can engage in other paid and unpaid activities to achieve it. In fact, for small and medium agricultural producers, the family is above all the basis of their economy and the objective of their productive strategies.

To quantify human work flows, and their reproduction cost, the Time Budget methodology should be used. It calculates the population's Time Use at any moment in time. The aggregate nature of this methodology, however, based on the scale of a state, makes it difficult to apply this technique. The aggregate information we dispose to quantify workflows is the standard information provided by Spanish statistics: the population that is active, employed or unemployed in the agricultural sector. We have assumed that such flows (whether paid or not, and whether directly agrarian or not) originate in farmer households or field workers whose reproductive costs must be covered by the monetary income received in exchange for production. Consequently, we have assumed that the reproduction of a farmer household is viable when agricultural income allows reaching the national average of household expenditure.

Human labor logically requires energy, basically endosomatic energy, to maintain and reproduce itself. In fact, this is the amount of energy that we used to calculate the energy efficiency of each of the successive metabolic arrangements over the study period, i.e. a century and a few years. Nevertheless, as human societies have been gaining in complexity, cost of reproduction has also increased to include all exosomatic energy incorporated in that process (or its equivalent in monetary terms). As the metabolic profile of contemporary societies has increased, the cultural consumption of energy and materials has been gaining importance-thus so has its monetary cost.

The fourth and last fund element considered is the technical means of production. Today it could be called "Technical Capital" as referred by Mario Giampietro and it includes instruments or substances that aim at replacing certain ecosystem functions and services such as pest control, fertility replacement, etc., which are manufactured outside the agricultural sector and through the use of fossil fuels or mineral sources. It also includes the set of artifacts created to perform all kinds of agricultural tasks. For example, they may consist in devices capable of converting fuel flows into tractor power flows in a localized manner to perform tasks that human work would not usually perform, either because they require a lot of power or because they save work. The capacity of this fund element is measured as we have seen in $\mathrm{kW}$ or cV (or hp) and has worked and still works with fossil fuels both for its manufacturing and functioning. The maintenance of this fund requires investment in energy and materials and, unlike the other funds, its replacement occurs thanks to metabolic processes that take place outside the agricultural sector itself. In this fund, and for purely formal purposes, we include cattle when used for fieldwork, measurable in $\mathrm{kW}$ or horse power, which depends instead on biomass metabolized in the form of grains, straw or grass for maintenance. As a biophysical fund, its size depends on the availability of food produced by agroecosystems and the nutrient needs and stocks of manure and other fertilizers; as a social fund, its size depends on traction needs (Graph 1.1). 


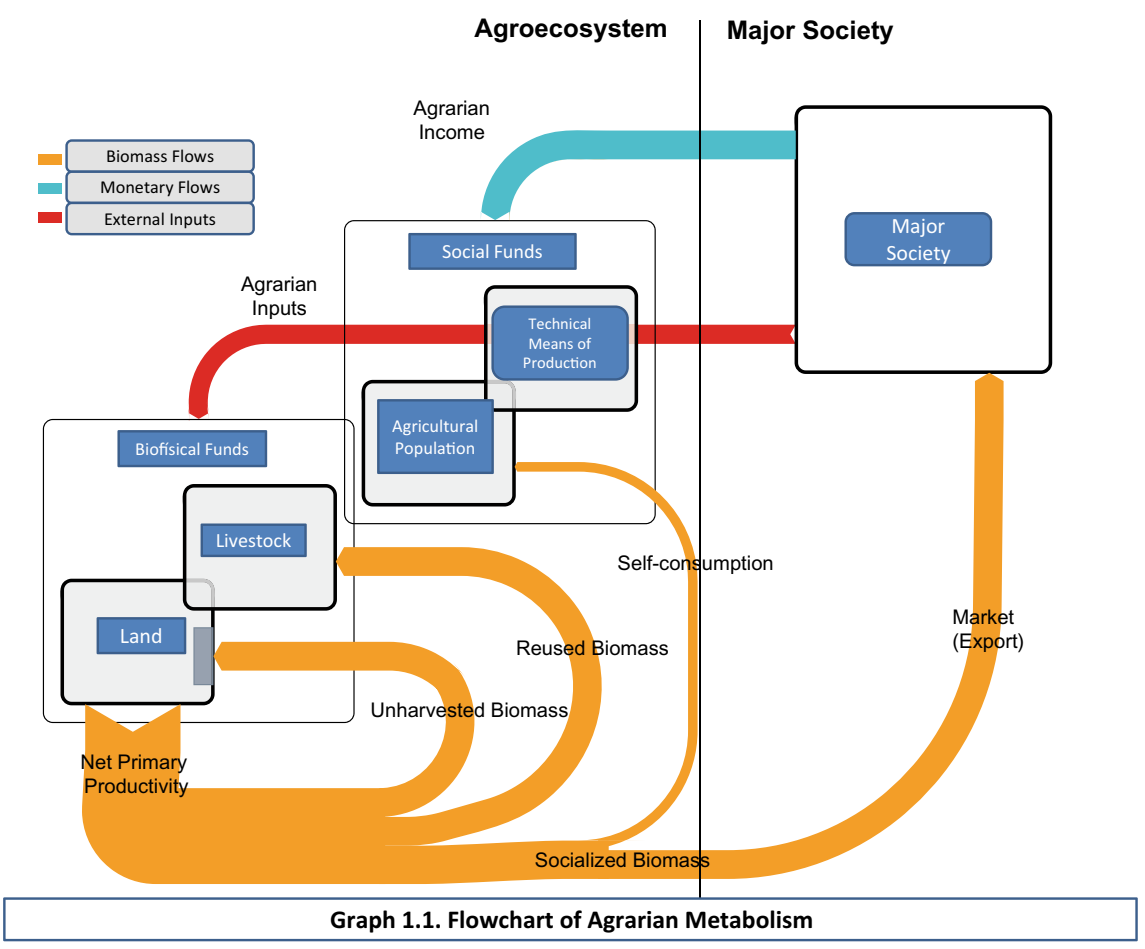

Graph 1.1 Flowchart of Agrarian Metabolism

\subsection{The Organization and Dynamics of Agrarian Metabolism}

The four fund elements that operate in AM mutually affect each other. This interrelation is expressed in each metabolic arrangement in a particular fashion, giving rise to a sort of unstable equilibrium that makes the AM function as a whole in a specific way. The ability to process energy and materials that each fund element has determines not only the magnitude of the flows it generates but also generates restrictions for others. Land availability and its capacity to produce biomass has a direct impact on the magnitude of the flows originating in human work, livestock or means of production. Low availability of human work can, for example, limit the capacity of the land to produce useful biomass, favoring, for example, livestock use of the land and vice versa; very strong traction power can lead to a more intensive agricultural use of the land that would not correspond to the size of the population and its capacity to work; while an excessive volume of the technical means of production or livestock may require importing energy from the outside, in the form of biomass or fossil fuels. This is what occurred, as we will see, with Spanish agriculture over the last half-century. 
The fund elements' mutual dependence not only explains the structure, functioning and dynamics of AM, but also constitutes the key to its degree of sustainability i.e., whether if each fund element is capable of providing the services required by AM itself to function (Giampietro et al. 2014, 19) and to do so in a balanced manner over time. The imbalance between each fund's capacity and the generated flows can make it necessary to seek a new equilibrium, thus causing changes that compromise the medium and long-term viability of the established metabolic arrangement. This consistency between flows and funds and among funds themselves is not found in the EW-MEFA methodology but in the MuSIASEM methodology, made operational through the so-called "sudoku effect" (Giampietro et al. 2014; Giampietro and Bukkens 2015). We incorporated this idea into our AM proposition to evaluate the sustainability or at least get an idea of it: a variable part of the energy and material flows must necessarily be invested in the maintenance and reproduction of the funds and these, in turn, must preserve the necessary relation of congruity in such a way that the flows originated in one fund can help the others to function and vice versa. In our view, the imbalances or lack of correspondence between the funds and their flows explain the metabolic dynamics and, therefore, tendencies towards unsustainability and towards metabolic change.

The study of metabolic dynamics and the processes of change indeed lies at the heart of this work. The objective is to understand why certain decisions were made leading AM to be in the situation it is in now. In social sciences, theories that explain long-term changes in human societies using the concept of transition have become increasingly relevant (Bergh and Bruinsma 2008; Lachman 2013). A academic trend that analyzes transition towards sustainability from a metabolic perspective has also been developed. According to this approach, which is linked to the IFF-Social Ecology of Vienna, socio-ecological transition processes are processes of structural change affecting the configuration of energy, material and information flows that societies exchange with their environment (Fischer-Kowalski and Rotmans 2009; Fischer-Kowalski 2011). However, this approach has been criticized by Lachman $(2013,274)$, and rightly so, because it interprets socio-metabolic transition at a system level that is overly abstract (social metabolism) and leaves no place for social actors. Factors such as beliefs, political or economic interests or culture-we call them information flows-are not taken into account. This inordinately general and abstract framework can hardly generate advice to its users on concrete policies to advance the transition. Our proposition, in line with this criticism, considers that social agents undeniably play a fundamental role. If we keep this in mind, information flows become central to the analysis.

Either way, Socioecological Transition is a conceptual tool that aims at making social and environmental change comprehensible by reducing its complexity. In this sense, the notion of socioecological transition allows us to understand the mechanisms underlying AM's shift from its organic configuration to its current industrial configuration, adopting in the process hybrid forms of variable duration, where AM is not totally organic nor totally industrial. With the industrialization of agriculture, AM specialized in the production of biomass to satisfy the endosomatic consumption of individuals as well as demands for industrial raw materials and services. AM has 
gone from being at the heart of the sociometabolic process, and its main source of energy, to constituting an apparently marginal segment of the process due to fossil fuel exploitation (González de Molina and Toledo 2011, 2014). The metabolic functionality of agrarian activities has therefore changed. They constitute just another input of the metabolism of materials. Though the market does not reward them for it, they offer essential environmental services (carbon sink, climate regulation, water purification, maintenance of certain levels of biodiversity, etc.) for the stability of industrial metabolism. Perhaps because of this, they have tended to deteriorate with the process of industrialization and commodification of agriculture (De Groot et al. 2002; Pagiola and Platais 2002).

According to the literature available, AM's socioecological transition that culminated with the industrialization of agriculture followed three major "waves" (González de Molina 2010): the first wave was driven by the institutional change that accompanied the implementation of liberalism, occurring within the limits of organic AM. It entailed "optimizing" its capacity to increase biomass production. During the second wave, AM underwent its first great metamorphosis related to partially unstructured biogeochemical cycles. The vector of this process was the appearance and diffusion of artificial fertilizers in the final decades of the nineteenth century and the beginning of the twentieth century. Its introduction meant "overcoming" the most common limiting factor of production until then, i.e., the lack of nutrients, and breaking the link of dependency between fertility replacement and land. A long transition process began in which agricultural production would shift from being dependent on soil to being dependent on the subsoil, in other words on fossil fuels and minerals. The third milestone of metabolic change opened the path towards the definitive metamorphosis of traditional organic agriculture. The energy transition was completed: fossil fuels replaced a large part of the workforce and all animal traction. AM was industrialized and the distinctive limitations of organic metabolism disappeared. It was associated with changes in energy patterns where coal was replaced with oil and natural gas, providing higher energy densities. Two basic industrialization innovations linked to these changes allowed to massively subsidize agriculture based on external energy: electricity and the internal combustion engine. Developments during the second and third of these three waves draw our special interest as they correspond to our study period.

All these changes eventually took place at different scales. At the crop scale, highly significant changes took place that mainly affected the genetic material, that is, seeds. Crop varieties or livestock breeds offering higher yields or certain productive characteristics were sought. At the farm level, connections between crops and polycultures were drastically reduced, rotations were simplified and they were subsequently replaced with crop alternations governed by market demands. Heterogeneous crops and plants as well as their combined distribution over fields gave way to monoculture, significantly reducing genetic, structural and functional diversity (Gliessman 1998). At the landscape scale, land uses were segregated and the productive and functional synergies generated by agrosilvopastoral integration were lost. The trend towards productive specialization grew ever stronger, imposing specialized land uses according to market demands rather than according to land capabilities or 
the presence of natural resources. Geodiversity and spatial heterogeneity were consequently lost. Thus, energy and material flows, which tended to be local and contained (renewable) ended up being global and originating from fossil sources. We will come back to this issue in the following section. Finally, on a more aggregate scale, agrarian systems have been integrated into a nationwide market, and this has fostered productive specialization based on comparative advantages and opportunity costs; this process has reached its peak today with the constitution of a global agrarian market and a global agri-food regime, in which agroecosystems are vertically integrated (McMichael 2009).

\subsection{The Forces of Change}

This research is dedicated to analyzing socio-metabolic changes in Spanish agriculture since 1900 and to uncover its driving forces. As we will see in the following chapters, the history of Spanish agriculture in the last century could be understood as a continuous effort to increase and specialize the volume of biomass production to face both the endosomatic and exosomatic demands of society. As a result, the main forces that drove the change, that is, the socioecological transition, were intensification and productive specialization. These occurrences were all similar to those in industrialized countries and to some extent to those in neighboring agricultures (IPES-Food 2016). They seem to have responded to a general trend.

In fact, Spanish agricultural developments since 1900 should be studied in the light of a more universal evolution. The notion of intensification refers to more intensive agricultural cultivation and growing use of inputs that generally lead to greater agricultural productivity. This seems to have been a general trend that has followed similar patterns across space and time (Mustard et al. 2004). To understand this process, Foley et al. $(2005,571)$ proposed a land-use sequence called Land Use Transitions mainly powered by productive intensity (Rudel et al. 2009; Lambin and Meyfroidt 2010; Jepsen et al. 2015). In a similar line, Ellis et al. (2013, 7980) recently advanced a Land Intensification Theory. Most of these processes include sustained increases in land productivity associated with more intensive management (Currie et al. 2015; Federico 2009). But the process does not seem to have been completely linear. Net primary productivity has not clearly increased in all cases (Smil 2011; Krausmann et al. 2013); and productivity doesn't seem to have grown continuously but has rather followed phases of involution and crisis (Ellis et al. 2013). Intensive land use has also been linked to drops in labor productivity in pre-industrial contexts, while in industrial contexts the opposite has occurred, labor productivity has increased at the same time (Fischer-Kowalski et al. 2014).

The most interesting debate, however, regards the causes of intensification. The most widely circulated hypothesis is based on the theories of Boserup (1965), according to which soil use intensity increases have been a response to population growth and a fall in available land. Many hypotheses are based on "demographic pressure" as the explanatory variable (Currie et al. 2015, 26). Nevertheless, in recent years 
the theses of Boserup and his followers have attracted growing criticism. Lambin et al. (2001) have fought against the idea that population and poverty are responsible for deforestation or that population growth drives unsustainable intensification, especially among small farmers. Other authors have limited the relationship between deforestation and population density to pre-industrial societies (Kaplan et al. 2009, 3031 ) or the viability of the Boserupian theory generally (Fischer-Kowalski et al. 2014). Ellis et al. (2013, 7980) suggest understanding intensification of land uses as an adaptive response, not only to demographic pressures but also to social and economic pressures. They do however warn that the intensification process is not linear, nor continuous or uniform. It can undergo steps forward and reversals. This explains, together with social, demographic and economic conditions, the existence of different land-use regimes. On the other hand, Kay and Kaplan (2015) maintain that the reasons for intensification are more complex than either the population or the social and economic variables. They suggest that a specific combination of a cluster of factors would explain land-use patterns. They described, based on archaeological records and other sources, the characteristic patterns of sub-Saharan Africa for 2500 years. According to the authors, these patterns reflect specific combinations of diet, technology, culture, subsistence or urbanization, which together lead to differentiated soil intensity patterns. Finally, some authors argue that land uses are a reflection of raw material flows, energy, population, information, etc., and call for new theoretical and methodological approaches to address their analysis (Friisa et al. 2015, 4).

In line with these latest contributions and our theoretical and methodological approach, particular configurations of land uses are more easily analyzed when they are understood as a specific metabolic design; productive intensification and specialization should be understood as a more general socioecological transition process (Fischer-Kowalski and Haberl 2007; Fischer-Kowalski et al. 2014; González de Molina and Toledo 2014). We must, therefore, address the factors underlying Spanish agriculture's intensification and productive specialization since 1900. These processes were the main drivers of the shift towards an industrial metabolic regime. The hypothesis we intend to verify is as follows: the agrarian population, a part of society and a center of metabolic activity, is at the intersection between the social and biophysical dimensions of AM; as such, the agrarian population forms its bond with the rest of society, providing certain quantities of animal and vegetal biomass and obtaining certain amounts of money in return in order to reproduce and, where appropriate, improve the fund elements. If the amount of monetary flow allows the agrarian population to easily reproduce itself, the surplus will be invested in improvements to the other funds or in increasing domestic consumption. But if the amount of monetary flow is insufficient for the agrarian population to reproduce itself based on the society's overall average exosomatic consumption levels, the most likely response is to intensify and/or specialize agricultural or livestock production or use more inputs, or all three at the same time. This can cause the reproduction cost of other funds to increase, bringing down household incomes, causing a vicious circle with increasingly intensive and specialized use of agroecosystems. 
In this work, we also contend that unequal access and distribution of agricultural resources and, therefore, of the satisfiers to meet the historically changing needs of farmers has had a decisive influence on intensification and productive specialization. Unequal allocation of AM fund elements among the agrarian population (internal inequality) is not the only cause of inequality, as is usually assumed. It is also the result of unequal exchanges between the agrarian sector and other urban-industrial sectors (external inequality) over the last century. In fact, the market has been a historical means of transfer of income from the agricultural sector to other sectors of activity (Bernstein 2010; Hornborg 2011, 5). Inequality, both internal and external, deteriorated farmers' incomes, who compensated by developing various strategies that stimulated intensification and/or productive specialization, pushing towards a socio-ecological transition. In short, the hypothesis we wish to establish in this book is that intensification and specialization efforts were linked to attempts to compensate for varying drops in agricultural income and employment during the 20th century. There has been a negative impact on the four funds: destruction of employment, strong livestock imbalances, disproportionate increase in technical means of production and deterioration of the land's environmental quality and its associated resources. The congruent links between the funds were broken and the reproduction conditions of AM seriously compromised.

\subsection{Sources and Methods}

To make the biophysical analysis of Spanish agriculture operational, it was necessary to adapt and combine existing metabolic methodologies (EW-MEFA, MuSIASEM) and add further instruments. Our proposal integrates several aspects not included in these latter methodologies and that result from hybridization with Agroecology.

\subsubsection{The Specificities of Agrarian Matabolism}

First, in accordance with the importance we have attributed to the fund element of reproduction, special attention is paid to what happens inside agroecosystems. We thus developed a specific methodology for calculating net primary productivity (NPP). It shares some of the assumptions of the HANPP (Human Appropriation of Net Primary Productivity) but distinguishes itself in some pivotal aspects. The HANPP only takes into account a part of net primary production, mainly Domestic Extraction (DE), and not the whole. This leaves out a large part of the impacts generated by different metabolic arrangements on the agrarian environment. Our methodological proposal takes into account all the NPP, both aerial and root parts. From the AM perspective, the NPP is of interest as a whole since it supports trophic chains. NPP establishes the limits of the maintenance capacity of heterotrophic populations: all members of the animal kingdom (human population, domesticated animals, and wild 
fauna), the fungi, a large part of the bacteria and the archaea. Therefore, appropriation by human societies of NPP affects the maintenance of the rest of heterotrophic organism populations that depend on the same resources.

To perform accurate calculations, we had to consider the productivity of both the cultivation areas and those dedicated to pastures and forestry. When all the biomass produced in agroecosystems is considered, a somewhat distinct perspective from that usually adopted in Social Metabolism (SM) studies can be taken. SM studies tend to center on society and the resources it appropriates. The problem is that they leave aside the structure and functioning of ecosystems, whose healthy ecological status depends on the supply of services that society receives. In other words, from an agroecological perspective, levels and sustainability of DE also depend on the biomass that is not extracted thus remaining available in the ecosystems for its other heterotrophic components. A detailed guide on how the calculation was performed for Spain and how it can be calculated for other territories can be found in Annex I. A detailed description of the different sections into which it has been broken down is also provided. Finally, we took into account all the year's biomass produced in the territory under study, that is, the totality of actual NPP. This approach distinguishes itself from that of usual social metabolism studies (Schandl et al. 2002; Imhoff et al. 2004; Haberl et al. 2007), which only take into account the amount of harvested, reused or useful biomass.

A final difference should be highlighted referring to the way in which biomass should be accounted for. The standard methodology (E-W MEFA) is based on distinguishing fresh matter products from dry matter products (mainly pastures and forage plants) (Eurostat 2013), thus adding different kinds of weights. The most rigorous way to consider all types of biomass is to reduce them all to dry matter, as commonly done in specific studies on agriculture from a biophysical perspective (Krausmann et al. 2008a, b; Smil 2013). This avoids distortions produced by the different water contents among types of biomass, especially between pastures and crops (between 15 and $95 \%$ ). Furthermore, this consideration is necessary to study, as in our case, the evolution of agricultural production. Crops with greater water content have become highly relevant (in horticultural production for example), to the detriment of other crops with lesser water content (cereals and legumes).

Secondly, in line with the Agroecology definition of agroecosystem, our AM proposition includes economic aspects that have been left out until now. This integration is performed via the study of the monetary flows that enter and leave the system. Society remunerates the agrarian sector for its products, whether agricultural, livestock or forestry products, and this remuneration constitutes the main inflow. Expenditures outside the sector, including expenses related to current means of production acquired on markets (commercial seeds and seedlings, that are not farm-reproduced nor exchanged between farmers, fuels and lubricants, fertilizers and amendments, feed, phytosanitary ware, material maintenance expenses, etc.) constitute the outflows. To quantify both flows, we used the macromagnitudes provided by Spain's national accounting and, more specifically, the agricultural sector accounts. The difference between both flows constitutes the gross value added (GVA) produced within agroecosystem boundaries. Agrarian income is obtained once depreciations, 
land taxes, fixed assets, or employed labor have been deducted, and the subsidies added together. This constitutes the flow of money with which to reproduce and improve, where appropriate, agrarian metabolism fund elements and, especially, the agrarian population. In this way, our AM proposal also integrates information flows that traditional methodologies do not contemplate.

Third, special attention is given to inequality in access and distribution of these monetary flows. Land tenure and means of production play a crucial role here. We already mentioned internal and external inequality: internal inequality was measured according to farm structures and the unequal distribution of agrarian income it introduces. To further refine this distribution, we distinguished between paid wages and entrepreneurial income. External inequality was measured through terms of trade with other sectors of activity and the evolution of agricultural income in constant values.

Fourth and last, our proposal makes it possible, unlike other methodologies, to measure both the social and environmental impacts generated by a specific metabolic arrangement on agroecosystems. The perspective we adopted here is as follows: an agroecosystem will be more sustainable if its fund elements are reproduced adequately through energy flows, materials, and information. This means that the agroecosystem's capacity to maintain biomass production in the long term, without relying on external inputs, is the chief manifestation of sustainable management. So far, methods for assessing agricultural sustainability have mainly relied on a battery of indicators of potential natural resource degradation problems, e.g., the "Framework to Assess Natural Resources Management Systems incorporating Sustainability Indicators" (Marco para la Evaluación de Sistemas de Gestión de Recursos Naturales que Incorporan Indicadores de Sostenibilidad, López-Ridaura et al. 2002) or the Sustainability Assessment of Farming and the Environment (SAFE) (van Cauwenbergh et al. 2007). However, their usefulness is limited because they do not reflect the functioning of the agroecosystem or describe the funds' reproduction mechanisms and, therefore, they do not reveal much about the processes that cause degradation or the interrelationships between them. Specific modes of calculation are detailed in the corresponding chapters.

\subsubsection{Scale and Bounderies of the Study}

Most metabolic studies have considered biomass as one of society's most essential materials. These studies have been conducted on a local or nationwide scale, covering all materials, biotic and abiotic, without specifically considering the agricultural sector as a unit of analysis. This work focuses on agroecosystems and its bounderies are those of any society's agrarian sector. It is characterized by the "production" of living organisms (biomass), a specificity shared by no other productive sector (except fishing). Given that the sector has required non-biotic inputs since the beginning of the twentieth century, our proposal of agrarian metabolism also considers both biotic and abiotic materials. This somewhat confounds the analysis as it is not possible 
to add apples to oranges, i.e., to mix biotic with abiotic factors without taking into account their different nature and indirect costs. But if we do not embrace this twofold analysis, it will be impossible to capture the significant change undergone by agrarian metabolism during its industrialization: from functioning almost exclusively on biotic materials at the start, it has become increasingly dependent on abiotic materials (metallic and non-metallic minerals and, above all, fossil fuels) for the manufacturing and operation of inputs. Future sustainable agriculture is faced with the challenge of minimizing the use of abiotic inputs and relying on biotic materials. Knowing the reasons for its progressive adoption in contemporary agriculture and its degree of dependence is decisive in planning the transition towards sustainable agrarian systems.

To summarize, AM includes the energy, materials and information exchanges contained within all agricultural activities in a given territory in order to produce vegetal or animal biomass for society, whether in the form of human or animal food, raw materials or fuels, and to provide basic ecosystem services, as for other ecosystems. Thus, any inputs not included in the list above, even if they originateas in our case-in the country itself, are considered imports in the same way that all plant or animal products that go out of the territory are considered exports, even if they end up in local society. What is the reason for this rule? In Agroecology, the closure of agroecosystem cycles and their autonomy regarding the market or other external agroecosystems are known to be an essential attribute of agrarian sustainability (González de Molina and Guzmán Casado 2017).

\subsubsection{Sources of Information}

The analysis of the evolution of Spanish agriculture has required the collection and processing of a huge amount of data. Until the end of the 19th century, no statistical information had been collected on surface areas, yields, and production of various crops. We dispose of annual production series for the most important crops-cereals, legumes, grapes, and olives - dating from the end of the 19th century until the 1930s (GEHR 1991). The missing information was reconstructed from complementary sources, namely annual reports published on various topics by the Agronomic Advisory Board. In this way, we have been able to make estimations of Spanish production for three periods: 1900, 1910, and 1922. As of 1929, annual series of agricultural production were published: as from 1929 in the Statistical Yearbooks of Agricultural Productions and as from 1972 in the Yearbooks of Agricultural Statistics. Based on these yearly sources, we calculated five-year averages around the years 1933, 1940, 1950, 1960, 1970, 1980, 1990, 2000, and 2008. We also used five-year averages to calculate biomass exports and imports, based on foreign trade sources.

To draw up magnitudes in biophysical terms we also considered all agricultural residues that were utilized in some way (mainly livestock), such as straw and stubble, foliage and branches or tuber and horticultural residues. We used historical sources for straw, foliage, and shoots. For the remaining residue, we used the converters 
provided by the literature, that we compiled (Guzmán et al. 2014, available at www. seha.info). Land uses were reconstructed based on the same sources, from which we calculated the production of pastures and fallows. For firewood and wood, we used our own estimate (Infante-Amate et al. 2014b) and that of Iriarte and Iriarte-Goñi and Ayuda (2008).

We reconstructed the subsector of livestock productions based on livestock censuses. To do this, we used data on meat and milk productions available in the 1930s Spanish Statistical Yearbooks of Agricultural Production applying coefficients corresponding to previous censuses. For fertilizer production, livestock food needs, and average weight of different species, we applied converters elaborated from the 1891 and 1917 livestock records. The biophysical approach presents a methodological advantage in that it enables detecting and correcting possible problems in the sources. By comparing livestock food needs, animal labor needs for agriculture, and the availability of livestock feed, we were able to correct or validate the amount of livestock provided by the censuses and livestock counts. A detailed description of the sources and our methodological decisions can be found in Annex I.

\section{References}

Adriaanse A, Bringezu S, Hammond A, Moriguchi Y, Rodenburg E, Rogich D, Schütz H (1997). Resource flows: the material basis of industrial economies. World Resour Inst, Washington

Altieri MA (1989) Agroecology: the science of sustainable agriculture. Westview Press, Boulder, Colorado

Ayres RU (2007) On the practical limits to substitution. Ecol Econ 61:115-128

Bernstein H (2010) Class dynamics of Agrarian change. Fernwood Publishing, Halifax, N. S

Boserup E (1965) The conditions of agricultural growth: the economics of agrarian change under population pressure. Aldine, Chicago, Ill

Bulatkin GA (2012) Analysis of energy flows in agroecosystems. Herald Russian Acad Sci 82(4):326-334

Burkhard B, Fath BD, Müller F (2011) Adapting the adaptive cycle: hypotheses on the development of ecosystem properties and services. Ecol Model 222:2878-2890

Cook S (1973) Zapotec stoneworkers: the dynamics of rural simple commodity production in modern mexican capitalism. Univesity Press of América, Mexico

Cornell S (2010) Valuing ecosystem benefits in a dynamic world. Climate Res 45:264-272

Costanza R (2012) Ecosystem health and ecological engineering. Ecol Eng 45:24-29

Cunfer G, Krausmann F (2009) Sustaining soil fertility: agricultural practice in the old and new worlds, Glob Envir 4:8-47. http://www.environmentandsociety.org/node/4791

Currie TE, Bogaard A, Cesaretti R, Edwards NR, Francois P, Holden PB, Hoyer D, Korotayev A, Manning J, Moreno Garcia JC, Oyebamiji OK, Cameron P, Turchin P, Whitehouse H, Williams A (2015) Agricultural productivity in past societies toward an empirically informed model for testing cultural evolutionary hypotheses. Cliodynamics 6(1):24-56

de Groot RS, Wilson MA, Boumans RMJ (2002) A typology for the classification, description and valuation of ecosystem functions, goods and services. Ecol Econ 41:393-408

de Groot R, van der Perk J, Chiesura A, van Vliet A (2003) Importance and threats determining factors for criticality of natural capital. Ecol Econ 44:187-204 
de Groot R, Alkemade R, Braat L, Hein L, Willemen L (2010) Challenges in integrating the concept of ecosystem services and values in landscape planning, management and decision making. Ecol Complex 7:260-272

Ekins P, Simon S, Deutsch L, Folke C, de Groot R (2003) A framework for the practical application of the concepts of critical natural capital and strong sustainability. Ecol Econ 44:165-185

Ellis EC, Kaplan JO, Fuller DQ, Vavrus S, Goldewijk KK, Verburg PH (2013) Used planet: a global history. PNAS 110(20):7978-7985

Eurostat (2013) Economy wide material flow accounts (EW-MFA): Compilation guide 2013. Luxemburgo: European Statistical Office

Fath BD, Jørgensen SE, Patten BC, Straškraba M (2004) Ecosystem growth and development. Biosystems 77:213-228

Federico G (2009) Feeding the world. Eco Hist Agric 1800-2000. Princeton. Princeton University Press

Fischer-Kowalski M (1998) Society's metabolism: the intellectual history of materials flow analysis, part I, 1860-1970. J Ind Ecol 2:61-77

Fischer-Kowalski M (2002) Exploring the history of industrial Metabolism. In: Ayres RU, Ayres LW (eds) A handbook of industrial ecology. Edward Elgar Publishing, Cheltenham, UK; Northampton MA, USA, pp 16-26

Fischer-Kowalski M (2011) Analyzing sustainability transitions as a shift between sociometabolic regimes. Environ Innov Soc Transit 1(1):152-159

Fischer-Kowalski M, Haberl H (2007) Socioecological transitions and global change: trajectories of social metabolism and land use. Institute of Social Ecology, Edward Elgar Publishing, Vienna, Austria

Fischer-Kowalski M, Haberl H (1997) Tons, joules, and money: Modes of production and their sustainability problems. Soc Nat Resour 10 (1):61-85

Fischer-Kowalski M, Rotmans J (2009) Conceptualizing, observing, and influencing socialecological transitions. Ecol Soc 14(2), art. 3

Fischer-Kowalski M, Krausmann F, Pallua I (2014) A sociometabolic reading of the anthropocene: modes of subsistence, population size and human impact on earth. Anthropocene Rev 1(1):8-33

Foley JA, Defries R, Asner GP, Barford C, Bonan G, Carpenter SR, Chapin FS, Coe MT, Daily GC, Gibbs HK, Helkowski JH, Holloway T, Howard EA, Kucharik CJ, Monfreda C, Patz JA, Prentice IC, Ramankutty N, Snyder PK (2005) Global consequences of land use. Science 309(5734):570-574

Folke C, Jansson Å, Rockström J, Olsson P, Carpenter SR, Chapin FS, Crepín AS, Daily G, Danell K, Ebbesson J, Elmqvist T, Galaz V, Moberg F, Nilsson M, Österblom H, Ostrom E, Persson A, Peterson G, Polasky S, Steffen W, Walker B, Westley F (2011) Reconnecting to the biosphere. Ambio 40:719-738

Friisa C, Østergaard Nielsen J, Otero I, Haberl H, Niewöhner J, Hostert P(2015) From teleconnection to telecoupling: taking stock of an emerging framework in land system science. J Land Use Sci 11(2):131-153. https://doi.org/10.1080/1747423X.2015.1096423

Garcia-Ruiz R, González de Molina M, Guzmán G, Soto D, Infante-Amate J (2012) Guidelines for Constructing Nitrogen, Phosphorus, and Potassium Balances in Historical Agricultural Systems. J Sustain Agric 36(6):650-682

Garrabou R, González de Molina M (2010) La reposición de la fertilidad en los sistemas agrarios tradicionales. Icaria, Barcelona

Garzón Casado B, Iniesta-Arandia I, Martín-López B, García-Llorente M, Montes C (2011) Entendiendo las relaciones naturaleza y sociedad de dos cuencas hidrográficas del sureste semiárido andaluz desde la historia socio-ecológica. VII Congreso Ibérico sobre Gestión y Planificación del Agua 'Ríos Ibéricos +10': mirando al futuro tras 10 años de DMA. Talavera de la Reina, España, pp 16-19 de febrero de 2011

GEHR (Grupo de Estudios de Historia Rural) (1991) Estadísticas Históricas de la producción agraria española, 1859-1935. Ministerio de Agricultura Pesca y Alimentación, Madrid 
Georgescu-Roegen N (1971) The entropy law and the economicprocess. Harvard University Press, Cambridge

Giampietro M, Bukkens S (2015) Analogy between Sudoku and the multi-scale integrated analysis of societal metabolism. Ecol Inf 26(1):18-28

Giampietro M Mayumi K, Sorman AH (2010) Assessing the quality of alternative energy sources: energy return on the investment (EROI), the metabolic pattern of societies and energy statistics. In: Working papers on environmental sciences, ICTA. Barcelona, Spain

Giampietro M, Mayumi K (2000) Multiple-scale integrated assessment of societal metabolism: introducing the approach. Popul Environ 22:109-154

Giampietro M, Mayumi K, Ramos-Martin J (2008) Multi-scale integrated analysis of societal and ecosystem metabolism (MUSIASEM). An outline of rationale and theory. In: Document de treball, Departament d'Economia Aplicada de la Universitat Autònoma de Barcelona. Barcelona

Giampietro M, Mayumi K, Sorman AH (2011) The metabolic pattern of societies: where economists fall short. Routledge, London

Giampietro M, Aspinallis RJ, Ramos-Martin J, Bukken SGF (eds) (2014) Resource accounting for sustainability assessment: the nexus between energy, food, water and land use. Routledge, London

Gierlinger S, Krausmann F (2012) The physical economy of united states of America. J Ind Ecol 16(3):365-377

Gliessman SR (1998) Agroecology. Ecological processes in sustainable agriculture. Lewis Publishers (CRC Press), Boca Ratón

Gliessman SR (2007) Agroecología: promoviendo una transición hacia la sostenbilidad. Ecosistemas 16(1):13-23

González de Molina M (2010) A guide to studying the socio-ecological transition in European agriculture. Documentos de Trabajo de la Sociedad de Estudios de Historia Agraria, $\mathrm{n}^{\circ}$ 10-06

González de Molina M, Guzmán Casado GI (2006) Tras los pasos de la insustentabilidad. Agricultura y Medio ambiente en perspectiva histórica (siglos XVIII-XX). Editorial Icaria, Barcelona

González de Molina M, Guzmán Casado G (2017) Agroecology and ecological intensification. A discussion from a metabolic point of view. Sustain 9(1):1-19

González de Molina M, Toledo V (2011) Metabolismos, naturaleza e historia. Una teoría de las transformaciones socio-ecológicas. Icaria, Barcelona

González de Molina M, Toledo V (2014) Social metabolism: a theory on socio-ecological transformations. Springer, New York

Grešlová P, Gingrich S, Krausmann F, Chromý P, Jančák V (2015) Social metabolism of Czech agriculture in the period 1830-2010. AUC Geogr 50(1):23-35

Guzmán Casado GI, González de Molina M (2000) Introducción a la Agroecología como desarrollo rural sostenible. Mundi-Prensa, Madrid

Guzmán Casado GI, González de Molina M (2009) Preindustrial agriculture versus organic agriculture: the land cost of sustainability. Land Use Policy 26:502-510

Guzmán Casado GI, González de Molina M, Alonso AM (2011) The land cost of agrarian sustainability: an assessment. Land Use Policy 28:825-835

Guzmán GI, González de Molina M (2017) Energy in agroecosystems: a tool for assessing sustainability. CRC Press, Boca Raton, FL

Guzmán GI, Aguilera E, Soto D, Cid A, Infante-Amate J, García-Ruiz R, Herrera A, Villa I, González de Molina M (2014) Methodology and conversión factors to estimate the net primary productivity of 112 historical and contemporary agro-ecosystems (I). Documento de Trabajo de la Sociedad Española de Historia Agraria, $\mathrm{n}^{\circ}$ 14-06. Disponible en: www.seha.info

Haberl H (2001) The energetic metabolism of societies. I: accounting concepts. J Ind Ecol 5:11-33

Haberl H, Erb KH, Krausmann F, Gaube V, Bondeau A, Plutzar C, Gingrich S, Lucht W, FischerKowalski M (2007) Quantifying and mapping the human appropriation of net primary production in earth's terrestrial ecosystems. Proc Nat Acad Sci 104(31):12942-12947

Häyhäa T, Franzese PP (2014) Ecosystem services assessment: a review under an ecologicaleconomic and systems perspective. Ecol Model 289:124-132 
Heller MC, Keoleian GA (2003) Assessing the sustainability of the US food system: a life cycle perspective. Agric Syst 76:1007-1041

Ho MW (2013) Circular thermodynamics of organisms and sustainable systems. Systems 1:30-49

Ho MW, Ulanowicz R (2005) Sustainable systems as organisms? BioSystems 82:39-51

Hornborg A (2011) Global ecology and unequal exchange: fetishism in a zero-sum world. Routledge, London

Iriarte-Goñi I, Ayuda MI (2008) Wood and industrialization. Ecol Econ 65(1):177-186

Infante-Amate J (2011) Los temporeros del olivar: una aproximación al estudio de las migraciones estacionales en el sur de España (siglos XVIII-XX). Revista de Demografía Histórica 29(2):87-118

Infante-Amate J, Aguilera E, González de Molina M (2014a) La gran transformación del sector agroalimentario español. Un análisis desde la perspectiva energética (1960-2010). Documento de Trabajo de la Sociedad de Estudios de Historia Agraria 14-03. https://ideas.repec.org/p/seh/ wpaper/1403.html

Infante-Amate J, Soto D, Iriarte Goñi I, Aguilera E, Cid A, Guzmán G, García Ruiz R, González de Molina M (2014b) La producción de leña en España y sus implicaciones en la transición energética. Una serie a escala provincial (1900-2000). Sociedad Española de Historia Agraria, Documento de Trabajo $\mathrm{n}^{\circ}$ 14-16. http://econpapers.repec.org/paper/ahedtaehe/1416.htm

Infante-Amate J, González de Molina M, Vanwalleghem, T, Soto Fernández D, Gómez Calero JA (2014c) Reconciling Boserup with Malthus. Agrarian change and soil degradation in olive orchards in Spain (1750-2000). In: Fischer-Kowalski M, Reenberg A, Schaffartzik A, Mayer A (eds) Ester Boserup's legacy on sustainability: orientations for contemporary research. Springer, New York, pp 99-116. https://doi.org/10.1007/978-94-017-8678-2_7

Infante-Amate J, Aguilera E, Palmeri F, Guzmán G, Soto D, García-Ruiz R, de Molina M González (2018) Land embodied in Spain's biomass trade and consumption (1900-2008): historical changes, drivers and impacts. Land Use Policy 78:493-502

Infante-Amate J, Soto, D, Aguilera, E, García Ruiz R, Guzmán, G, Cid A, González de Molina M (2015: The Spanish transition to industrial metabolism long-term material flow analysis (1860-2010). J Ind Ecol 19(5):866-876. https://doi.org/10.1111/jiec.12261

IPES-FOOD (International Panel of Experts on Sustainable Food Systems) (2016) From uniformity to diversity: a paradigm shift from industrial agriculture to diversified agroecological systems www.ipes-food.org

Jepsen MR, Kuemmerle T, Müller D, Erb K, Verburg PH, Haberl H, Vesterager JP, Andrič M, Antrop M, Austrheim G, Björn I, Bondeau A, Bürgi M, Bryson J, Caspar G, Cassar LF, Conrad E, Chromý P, Daugirdas V, van Eetvelde V, Elena-Rosselló R, Gimmi U, Izakovicova Z, JAN`CÁK V, Jansson U, Kladnik D, Kozak J, Konkoly-Gyuró E, Krausmann F, Mander U, McDonagh J, Pärn J, Niedertscheider M, Nikodemus O, Ostapowicz K, Pérez-Soba M, Pinto-Correia T, Ribokas G, Rounsevell M, Schistou D, Schmit C, Terkenli TS, Tretvik AM, Trzepacz P, Vadineanu A, Walz A, Zhllima E, Reenberg A (2015) Transitions in European land-management regimes between 1800 and 2010. Land Use Policy 49:53-64

Jørgensen SE, Fath BD (2004) Application of thermodynamic principles in ecology. Ecol Complex $1: 267-280$

Jørgensen SE, Fath BD, Bastianoni S, Marques JC, Müller F, Nielsen SN, Tiezzi E, Ulanowicz RE (2007) A new ecology: systems perspective. Elsevier Press, Amsterdam

Kaplan JO, Krumhardt KM, Zimmermann N (2009) The prehistoric and preindustrial deforestation of Europe. Quatern Sci Rev 28(27-28):3016-3034

Kay AU, Kaplan JO (2015) Human subsistence and land use in sub-Saharan Africa, 1000 BC to AD 1500: a review, quantification, and classification. Anthropocene 9:14-32

Kovanda J, Hak T (2011) Historical perspectives of material use in Czechoslovakia in 1855-2007. Ecol Ind 11(5):1375-1384

Krausmann F (2004) Milk, manure, and muscle power. Livestock and the transformation of preindustrial agriculture in Central Europe. Hum Ecol 32:735-772 
Krausmann F, Erb KE, Gringrich S, Lauk C, Haberl H (2008a) Global patterns of socioeconomic biomass flows in the year 2000: a comprehensive assessment of supply, consumption and constraints. Ecol Econ 65:471-487

Krausmann F, Fischer-Kowalski M, Schandl H, Eisenmenger N (2008b) The global sociometabolic transition: past and present metabolic profiles and their future trajectories. $\mathrm{J}$ Ind Ecol 12(5-6):637-656

Krausmann F, Gingrich S, Nourbakhch-Sabet R (2011) The metabolic transition in Japan. J Ind Ecol 15(6):877-892

Krausmann F, Erb KH, Gingrich S, Haberl H, Bondeau A, Gaube V, Lauk C, Plutzar C, Searchinger TD (2013) Global human appropriation of net primary production doubled in the 20th century. PNAS 110(25):10324-10329. http://dx.doi.org/10.1073/pnas.1211349110

Kusova, P, Gringrich, S, Krausmann F (2008 Long term changes in social metabolism and land use in Czechoslovakia, 1830-2000: An energy transition under changing political regimes. Ecol Econ 68(1-2):394-407. https://doi.org/10.1016/j.ecolecon.2008.04.006

Lachman DA (2013) A survey and review of approaches to study transitions. Energy Policy 58:269-276

Lambin EL, Turner BL, Geist HJ, Agbola SB, Angelsen A, Bruce JW, Coomes OT, Dirzo R, Fischer G, Folke C, George PS, Homewood K, Imbernon J, Leemans R, Li X, Moran EF, Mortimore M, Ramakrishnan PS, Richards JF, Skanes H, Steffen W, Stone GD, Svedin U, Veldkamp TA, Vogel $\mathrm{C}, \mathrm{Xu} \mathrm{J}$ (2001) The causes of land-use and land-cover change: moving beyond the myths. Glob Environ Change 11(4):261-269

Lambin EF, Meyfroidt P (2010) Land use transitions: Socio-ecological feedback versus socioeconomic change. Land Use Policy 27(2):108-118

López-Ridaura M, Masera O, Astier M (2002) Evaluating the sustainability of complex socioenvironmental systems. The MESMIS framework. Ecol Ind 2(1-2):135-148

Imhoff ML, Bounoua L, Ricketts T, Loucks C, Harriss R, Lawrence WT (2004) Global patterns in human consumption of net primary production. Nat 429 (6994):870-873

Matthews E (2000) The weight of nations: material outflows from industrial economies. World Resources Institute, Washington DC

Millennium Ecosystem Assessment (2005) Ecosystems and human well-being: synthesis. Island Press, Washington, DC

Mustard JF, Defries RS, Fisher T, Moran EF (2004) Land-use and land-cover change pathways and impacts. In: Gutman G, Janetos AC, Justice CO, Moran EF, Mustard JF, Rindfuss RR, Skole D, Turner BL II, Cochrane MA (eds) Land change science. observing, monitoring and understanding trajectories of change on the earth's surface. Kluwer Academic Publishers, Boston, pp 411-430

Pagiola S, Platais G (2002) Payments for environmental services, environment strategies, No. 3. The World Bank, Washinton, DC

Prigogine I (1947) Etude thermodynamique des phénomènes irreversibles. Dunod, París

Prigogine I (1962) Non-equilibrium statistical mechanics. Interscience, New York

Prigogine I (1978) Time structure and fluctuations. Science 201:777-785

Risku-Norja H (1999) The total material requirement-concept applied to agriculture: a case study from Finland. Agric Food Sci Finland 8:393-410

Risku-Norja H, Mäenpää I (2007) MFA model to assess economic and environmental consequences of food production and consumption. Ecol Econ 60(4):700-711. https://doi.org/10.1016/ j.ecolecon.2006.05.001

Rudel TK, Schneider L, Uriarte M, Turner BL II, Defries R, Lawrence D, Geoghegan J, Hecht S, Ickowitz A, Lambin EF, Birkenholtz T, Baptista S, Grau R (2009) Agricultural intensification and changes in cultivated areas, 1970-2005. PNAS 106(49):20675-20680

Schandl H, Schulz N (2002) Changes in the United Kingdom's natural relations in terms of society's metabolism and land-use from 1850 to the present day. Ecol Econ 41(2):203-221

Schandl H, Grünbühel C, Haberl H, Weisz H (2002) Handbook of physical accounting. Measuring bio-physical dimensions of socio-economic activities MFA-EFA-HANPP. In: Social ecology, Working Paper 73. Vienna. IFF

Scheidel A, Sorman AH (2012) Energy transitions and the global land rush: ultimate drivers and persistent consequences. Glob Environ Change 22(3):559-794 
Schröter M, Barton DN, Remme RP, Hein L (2014) Accounting for capacity and flow of ecosystem services: a conceptual model and a case study for Telemark, Norway. Ecol Ind 36:539-551

Sieferle RP (2001) The subterranean forest: energy systems and the industrial revolution. White Horse Press, Cambridge, UK

Sieferle RP (2011) Cultural evolution and social metabolism. Geogr Ann Ser B Hum Geogr 93(4):315-324

Singh, SJ, Krausmann F, Gingrich S, Haberl H, Erb KH, Lanz P (2012) India's biophysical economy, 1961-2008. Sustainability in a national and global context. In: Ecological economics, No 76, pp 60-69. https://doi.org/10.1016/j.ecolecon.2012.01.022

Smil V (2011) Harvesting the biosphere: the human impact. Popul Dev Rev 37(4):613-636. https:// doi.org/10.1111/j.1728-4457.2011.00450.x

Smil V (2013) Harvesting the biosphere: what we have taken from nature. The MIT Press, London Swannack TM, Grant WE (2008) Systems Ecology. In: Jørgensen SE, Fath BD (eds) Encyclopedia of ecology. Elsevier, Oxford, pp 3477-3481

Swanson GA, Bailey KD, Miller JG (1997) Entropy, social entropy and money: a living systems theory perspective. Syst Res Behav Sci 14(1):45-65

Tello E, Garrabou, R, Cussó X, Olarieta JR, Galán E (2012) Fertilizing methods and nutrient balance at the end of traditional organic agriculture in the Mediterranean bioregion: Catalonia (Spain) in the 1860s. Hum Ecol 40(3):369-383. http://dx.doi.org/10.1007/s10745-012-9485-4

Toledo V (1993) La racionalidad ecológica de la producción campesina. In: Sevilla E, González de Molina M (eds) Ecología, campesinado e Historia. La Piqueta, Madrid, pp 197-218

Toledo V, Barrera-Bassols N (2008) La memoria biocultural. La importancia agroecológica de las sabidurías tradicionales. Icaria, Barcelona

Ulanowicz RE (1983) Identifying the structure of cycling in ecosystems. Math Biosci 65:210-237

Ulanowicz RE (2004) On the nature of ecodynamics. Ecological Complexity 1:341-354

van Cauwenbergh N, Biala K, Bielders C (2007) SAFE-a hierarchical framework for assessing the sustainability of agricultural systems. Agr Ecosyst Environ 120(2-4):229-242

van der Bergh J, Bruinsma F (2008) Managing de transition to renewable energy. Theory and practice from local, regional and macro perspectives. MPG Books Ltd., Bodmin

Weisz H, Krausmann F, Amann C, Eisenmenger N, Erb KH, Hubacek K, Fischer-Kowalski M (2006) The physical economy of the European Union: crosscountry comparison and determinants of material consumption. Ecol Econ 58(4):676-698

Widgren M (2007) Precolonial landesque capital: a global perspective. In: Hornborg A, Mcneill JR, Martínez-Alier J (eds) Rethinking environmental history: world-system history and global environmental change. Altamira Press, Lanhan, pp 61-78

Wirsenius S (2003) The biomass metabolism of the food system. A model-based survey of the global and regional turnover of food biomass. J Ind Ecol 7(1):47-80

Open Access This chapter is distributed under the terms of the Creative Commons Attribution 4.0 International License (http://creativecommons.org/licenses/by/4.0/), which permits use, duplication, adaptation, distribution and reproduction in any medium or format, as long as you give appropriate credit to the original author(s) and the source, a link is provided to the Creative Commons license and any changes made are indicated.

The images or other third party material in this chapter are included in the work's Creative Commons license, unless indicated otherwise in the credit line; if such material is not included in the work's Creative Commons license and the respective action is not permitted by statutory regulation, users will need to obtain permission from the license holder to duplicate, adapt or reproduce the material.

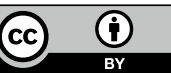

